\title{
A MAGYAR SPORT TERÜLETI VERSENYKÉPES- SÉGÉNEK VIZSGÁLATA TÖBBVÁLTOZÓS STATISZTIKAI MÓDSZEREKKEL
}

\author{
(The Analysis of the Regional Competitiveness \\ of the Hungarian Sport with Multivariable Statistical Methods)
}

\section{ÁCS PONGRÁC}

Kulcsszavak:

terïleti versenyképesség sport statisztika

Jelen tanulmány a hazai és a nemzetközi szakirodalomnak megfelelve a rendelkezésre álló és a szerzö által gyüjtôtt statisztikai adatokra hagyatkozva a hazai sport területi versenyképességét vizsgálja. A cikk középpontjában a többváltozós statisztikai módszerekre hagyatkozva a magyarországi sport területi versenyképességi rangsorának meghatározása áll. A tanulmány áttekinti a sport versenyképességére ható tényezöket, majd meghatározza a hazai területi sportklasztereket.

\section{Bevezetés}

Napjainkban a sport az egyre bővülỏ szórakoztató ipar része, amely a társadalom homlokterében álló jelenségek közül az egyik leglátványosabb növekedést produkáló terület. A gyorsan növekedỏ sportgazdaságba napjainkban egyre több pénz áramlik. Elmondhatjuk, hogy ennek a középpontjában a sporteredmények, sportteljesítmények állnak. A sporteredményekért számos tényező felelős, és ezeknek a térbeli megjelenése nem egyenletes.

A következő ábra a sportteljesítményre ható tényezőket szemlélteti (1. ábra).

\section{1. ÁBRA}

A sportteljesitményeket meghatározó tényezök

(Sport Performance Factors)

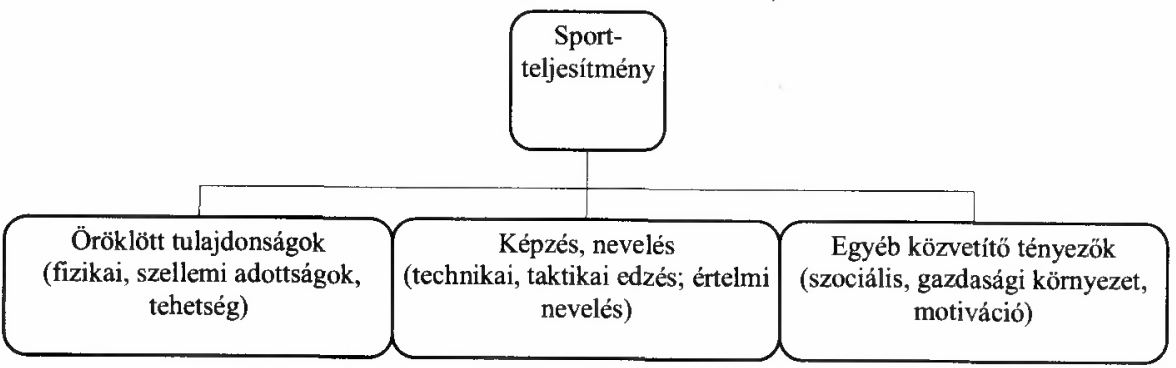

Forrás: Saját szerkesztés. 
Egy már meglévő kutatásunk a sportteljesítmények első két „faktorával” foglalkozik, amely végén azt az eredményt kaptuk, hogy az öröklött tulajdonságok és a képzés helye szerint Magyarországon nyugati dominancia érezhető. Az egyéb tényezőket olyan szinten vizsgáltuk, hogy az öröklött tulajdonságok területi megjelenésével mely tényezők és milyen erős kapcsolatban állnak. Jelen kutatás az egyéb közvetítő tényezőkön keresztül - a statisztika többváltozós módszereivel - mutatja be a sport területi versenyképességét Magyarországon.

\section{Területi versenyképesség}

A területi versenyképességgel számtalan kutató foglalkozott, de a sport területén ilyen elemző munka még nem készült. Miként határozható meg a területi versenyképesség?

A sport területi versenyképessége mindenképpen egy olyan folyamat, ahol a szereplök között megtalálhatók a nyertesek és a vesztesek egyaránt, mivel a szükös források elosztásáért folyik a rivalizálás.

Chikán és Czakó szerint a versenyképességnek alapvetően két dimenziója van, egyrészt a nemzetgazdasági versenyképesség alapját jelentő domináns tényezöcsoportok típusa (erőforrások, befektetések, innovációk), másrészt a verseny kiterjedtsége, azaz a külgazdasági kapcsolatokban való részvétel mértéke (hazai, nemzetközi, regionális, vagy globális) (Chikán-Czakó 2002).

„A régiók és városok akkor versenyképesek, ha gazdaságuk nyitott és az egy lakosra jutó jövedelmük tartósan magas és növekvő, valamint magas szintü és nem csökkenő a foglalkoztatottsági ráta, azaz ebböl a jövedelemböl a lakosság széles rétegei is várhatóan részesülnek." (Lengyel-Rechnitzer 2000,137)

Másként fogalmazva: „A régió nem közvetlenül versenyez, nem közvetlenül mérettetik meg, hanem gazdasági szereplöinek versenyképességén és lakosainak 'versenyképes' életszinvonalán, elégedettségén keresztül." (Palkovits 2000, 121)

A sport területén versenyképesnek tekinthetünk egy területet, ha stratégiailag beágyazott gazdasági bázisa a piaci értéken megvásárolva optimálisan jól használja az erőforrásait, miközben tartós előnyöket szerez a nemzetközi piacon. Megítélésünk szerint azt a területet tekinthetjük a sport terén versenyképesnek, amely a rendelkezésre álló erőforrásokat olyan sporteredménnyé alakítja, amely alkalmas a folyamatosan fejlödő, magas igényeket támasztó világpiaci kereslet kielégítésére. Ez az eredmény- és teljesítmény-központú megközelítés lehet a helyi sportpolitika célja.

A területek versenyének keresleti és kínálati oldalát megkülönböztetve azt mondhatjuk, hogy amíg a keresleti oldalon a területek céljai, addig a kínálati oldalon a területek adottságai jelennek meg. Kijelenthetjük, hogy ezek együtt határozzák meg a terület versenyképességi pozícióját.

A múltban a sporttelephelyek kiválasztásában a helyi adottságoknak, a meglévő eröforrásoknak, a helyi társadalom nyújtotta kedvezöbb feltételeknek, a demográfiai, a társadalmi-kulturális, természeti környezetnek nem volt túlzott jelentőségú szerepe. 
A felülröl irányitott - versenynek egyáltalán nem nevezhető - folyamatokat áthatotta a sportegyesület-telepítés „modellszerü” gyakorlata: a települések vezetőinek személyes kapcsolatai és a közigazgatási szerepkör és -besorolás elsődlegessége.

A kilencvenes években a sportban is három párhuzamosan megjelenő regionális és egyben területi változást érezhettünk (Nemes Nagy 1999):

1) a főváros kiemelkedő fejlödését az ország többi területéhez viszonyítva;

2) a vidéki térségeken belül a nyugati részek erőteljesebb növekedését a keleti részekhez képest;

3) erős gazdasági alapú tagoltságot a kistérségek szintjén, leginkább falu-város relációban.

A területi presztizs kapcsán Horváth összegyüjtötte azokat az intézményeket, amelyek egy területnek - nála városnak - versenyképességi előnyt adhatnak: egyetem, repülőtér, vásári, kiállitási létesítmények, külföldi képviseletek, tudományoskutatási parkok (Horváth 1998).

A sport területi versenyképességének térbeli tagozódása egyértelmủen az ,üzleti sport" megjelenésére vezethetô vissza. A magyar térszerkezetben kibontakozó eltérő fejlődési pályák a termelési tényezők egyenlötlen területi eloszlásával magyarázhatóak, ami a gazdasági értelemben használatos élsportra is igaz (Horváth 2001).

\section{A sport területi versenyképességét befolyásoló indikátorok bemutatása}

A következőkben arra vállalkozunk, hogy a sport versenyképességére ható tényezöket külön-külön elemezve próbáljunk egy komplex képet adni a sportban fellelhető területi különbségekre.

Nem kívánunk nagyon eltérni a hazai szakirodalom által a területi egyenlötlenségek mérésekor leggyakrabban használt indikátoroktól, melyek az alábbi változókhoz sorolhatók (Berey-Nemes Nagy 2002):

- demográfiai jelzőszámok,

- gazdasági jelzőszámok,

- infrastrukturális jelzőszámok,

- társadalmi jelzô számok.

Saját mutatóink elkészítésekor egy kis változtatást végeztünk, mely alapján a társadalmi mutatóhoz bevettük a demográfiára vonatkozó változókat, és egy új sporteredményességi mutatót is szerkesztettünk. A sporteredményességi mutatóban a hivatásos „profi” sportolókat vizsgáltuk. Természetesen az egyéni sportolók (olimpiai kerettagok) és egyesületeik száma mellett a föbb labdajátékok (labdarúgás, kézilabda, kosárlabda, röplabda, asztalitenisz) egyesületeinek területi előfordulásának a száma is szerepel.

$\mathrm{Az}$ általunk készített mutatókat és a bennük szereplő változókat ( $22 \mathrm{db})$ az 1. táblázat tartalmazza. 


\begin{tabular}{|c|c|}
\hline \multicolumn{2}{|c|}{$\begin{array}{c}\text { 1. TÁBLÁZAT } \\
\text { A vizsgált mutatók táblázata } \\
\text { (Variable of Resarch) }\end{array}$} \\
\hline A mutató neve & Bennük található változók \\
\hline Sporteredményességi mutató & $\begin{array}{l}\text { Olimpiai keret sportolók száma; } \\
\text { Olimpiai keret sportolókat adó sportegye- } \\
\text { sületek száma; } \\
\text { Első osztályú labdarúgó, kézilabda, kosár- } \\
\text { labda, röplabda, asztalitenisz csapatok } \\
\text { száma. }\end{array}$ \\
\hline Gazdasági mutató & $\begin{array}{l}\text { Külföldi érdekeltségú vállalkozások év } \\
\text { végi száma 2004; } \\
\text { Regisztrált vállalkozások száma 2004; } \\
\text { Egy fóre jutó GDP 2003; } \\
\text { Az ipar termelése területi egységek sze- } \\
\text { rint } 2004 \text { (millió Ft); } \\
\text { Nonprofit vállalkozások száma } 2004 \text {. }\end{array}$ \\
\hline Infrastrukturális mutató & $\begin{array}{l}\text { Sportegészségügyi rendelök száma 2004; } \\
\text { Főfoglalkozású sportorvosok száma 2004, } \\
\text { Felsóoktatási intézmény 2004; } \\
\text { Szállodák (Hotelek) száma 2004; } \\
\text { Az összes kereskedelmi szálláshely férö- } \\
\text { helyeinek a száma 2004; } \\
\text { Sportlétesítmények száma 2004; } \\
\text { Strandok száma } 2004 \text {. }\end{array}$ \\
\hline Társadalmi mutató & $\begin{array}{l}\text { Népesség száma 2004; } \\
\text { Alkalmazásban állók száma 2004; } \\
\text { Felsőoktatásban tanulók száma } 2004 .\end{array}$ \\
\hline
\end{tabular}

Forrás: Saját szerkesztés.

A számolás hitelességéhez azokat a változókat, amelyeknél ez szükséges volt, 100 ezer lakosra vetítve használtuk. A megfigyelési egységek a megyék és a fóváros voltak, az adatokat a Központi Statisztikai Hivatal aktuális kiadványaiból és az egyes sportági szövetségektől gyüjtöttük. A változók, feltételezéseink szerint, kapcsolatban állnak a sporttal. Feltételezéseinket a fent említett kutatásra, illetve a személyes 20 éves sportolói és sportvezetői múlt tapasztalataira alapoztuk.

A kutatásban prezentált eredményeket a többváltozós statisztikai elemzésekhez gyakran használt SPSS programmal végeztük.

\section{Módszertan}

Először az egyes „,mutatókon” végeztünk elemzést, melyben a változókhoz eredményességi pontszámokat ( 1 - legrosszab; 20 - legjobb) rendeltünk, majd ezeket összegeztük és átlagoltuk. A kapott átlagok alapján elkészítettük az adott mutató területi sorrendjét (2. táblázat). 


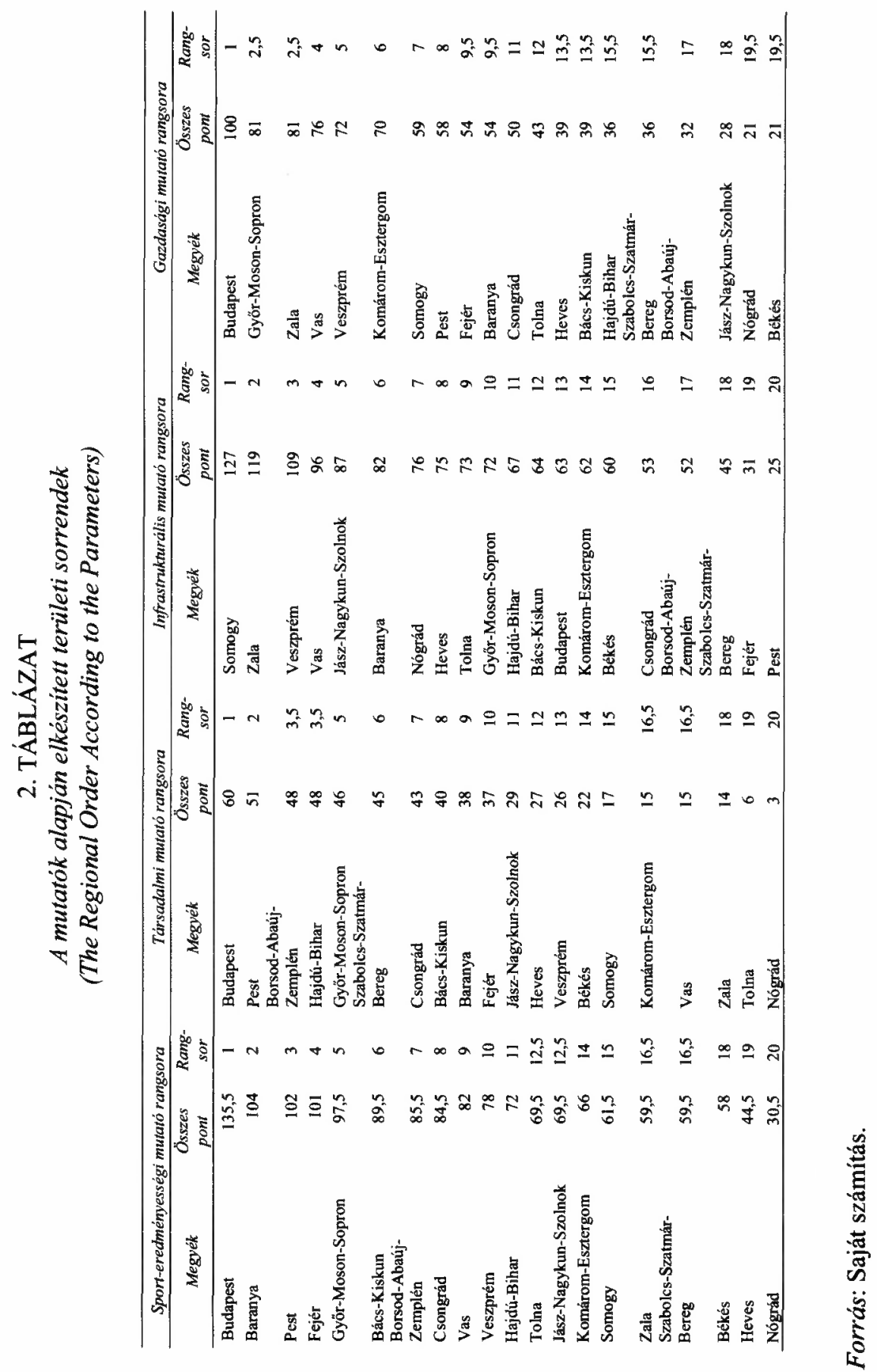


A táblázat adatai alapján megállapítható, hogy a sport területi versenyképességének vizsgálatához használt mutatók közül az infrastrukturális mutató kivételével mindenhol a föváros található a legelökelöbb helyen. A legrosszabb helyzetben ezen aggregát változók alapján Nógrád megye található. A táblázatból leolvasható a pontszámok alapján -, hogy leginkább a sporteredményességi mutatóban lelhetó fel területi koncentráció, mert a többi mutatóban a pontszámok eloszlása viszonylag egyenletes. Az aggregát-mutatók által készített minősítés önmagában is komplex mutatónak minősül.

Az aggregát mutatók elkészítése után felmerül az igény egy közös komplex mutató elkészítésére. Mivel a mutatók különböző számú változókat tartalmaznak, ezért az összegzés után a változók számával osztottuk a pontszámokat. Az így keletkezett értékek alapján elkészítettük a sport versenyképességének területi rangsorát, melyben az aggregát-mutatók egyforma súllyal szerepelnek (3. táblázat).

\section{TÁBLÁZAT}

A sport versenyképességének területi sorrendje, pontozásos módszerrel

(The Final Rankings According to the Parameters)

\begin{tabular}{lcc}
\hline \multicolumn{3}{c}{ Komplex területi sorrend } \\
\hline \multicolumn{1}{c}{ Megyék } & $\begin{array}{c}\text { Összes } \\
\text { pont }\end{array}$ & Rangsor \\
\hline Budapest & 66,50 & 1 \\
Györ-Moson-Sopron & 52,84 & 2 \\
Veszprém & 50,11 & 3 \\
Zala & 48,13 & 4 \\
Vas & 48,06 & 5 \\
Baranya & 47,80 & 6 \\
Somogy & 47,30 & 7 \\
Pest & 46,74 & 8 \\
Borsod-Abaúj-Zemplén & 41,61 & 9 \\
Hajdú-Bihar & 40,77 & 10 \\
Csongrád & 40,50 & 11 \\
Bács-Kiskun & 40,44 & 12 \\
Fejér & 39,94 & 13 \\
Komárom-Esztergom & 39,86 & 14 \\
Jász-Nagykun-Szolnok & 37,53 & 15 \\
Heves & 34,01 & 16 \\
Szabolcs-Szatmár-Bereg & 33,84 & 17 \\
Tolna & 33,39 & 18 \\
Békés & 25,71 & 19 \\
Nógrád & 22,99 & 20 \\
\hline
\end{tabular}

Forrás: Saját számítás.

Az elöző táblázatok után nem meglepő, hogy a rangsor elején Budapest található. A leggyengébb besorolást Nógrád és Békés megye kapta. 
Ezt követöen egy klaszteranalízis segítségével kategorizáltuk a területeket. Megvizsgáltuk, hogy mely megyék a legversenyképesebbek, melyek a feltörekvők és melyek az elmaradottak.

\section{A klaszteranalizis eredményei}

A heterogén sokaságot alkotó objektumok homogén csoportokra bontása a statisztikai elemzés egyik alapvető mozzanata. A csoportokat a sokaságról rendelkezésre álló információ tőmörítésére, továbbá az egyedit jellemző tulajdonságok statisztikai kapcsolatának a vizsgálatára, elörejelzésére használjuk. Értelemszerü, hogy relatíve kevés csoport kialakítására törekszünk. A fenti elvárásoknak eleget tevő alcsoportokat klasztereknek nevezzük.

Az SPSS programmal elvégzett vizsgálat Magyarország teruleteit a sportversenyképesség alapján három csoportba (klaszterbe) sorolta, melyek az adott változók szempontjából szignifikánsan különböznek egymástól.

$\mathrm{Az}$ első klaszterben azok a megyék szerepelnek, amelyek Magyarországon a sport szempontjából a legversenyképesebbek, a sporteredményességben, gazdaságban, társadalmi mutatók szerint előkelő rangsorolásuk van. Az infrastrukturális mutatóban azonban nem állnak a rangsor elején. Ezen megyékben viszonylag magas a népesség száma, a sporteredmények nagyon jók, és a gazdaság is jól müködik. A második klaszterben a versenyképesség szempontjából leszakadó területeket találjuk, melyeket közepes sporteredmények, viszonylag magas népesség, de gyenge infrastrukturális és gazdasági adottságok jellemeznek. Ezek azok a megyék, amelyek a múltban államilag támogatott gazdaság révén kiemelkedő sporteredményeket „termeltek”. Mivel ezek az adottságok kimerültek, így a gazdasági mutatók gyengülése révén a sporteredményeik, sportteljesítményeik is gyengülnek. A harmadik csoportban a feltörekvő megyék találhatók. Alacsony népességi és sporteredményességi adottságokkal, viszont magas infrastrukturális és gazdasági mutatóval rendelkeznek. Mivel a gazdaság jól mükődik, a sportot szolgáló infrastrukturális adottságaik jók, ezért a jövöben a sporteredményességi mutatóban is javulás várható (4. táblázat).

\section{TÁBLÁZAT}

Sport-versenyképességi klaszterek Magyarországon

(Sport-cluster in Hungary)

\begin{tabular}{lll}
\hline I. Klaszter & II. Klaszter & III. Klaszter \\
\hline
\end{tabular}

\begin{tabular}{|c|c|c|}
\hline $\begin{array}{l}\text { Budapest, Baranya, Fejér, } \\
\text { Győr-Moson-Sopron, Pest }\end{array}$ & $\begin{array}{l}\text { Bács-Kiskun, Békés, Borsod- } \\
\text { Abaúj-Zemplén, Csongrád, } \\
\text { Hajdú-Bihar, Jász-Nagykun- } \\
\text { Szolnok, Szabolcs-Szatmár- } \\
\text { Bereg }\end{array}$ & $\begin{array}{l}\text { Heves, Komárom- } \\
\text { Esztergom, Nográd, } \\
\text { Somogy, Tolna, } \\
\text { Vas, Veszprém, Zala }\end{array}$ \\
\hline
\end{tabular}

Forrás: Saját számítás. 


\section{A faktoranalizis eredményei}

A kapott pontozásos módszer ellenőrzéseként az aggregát-mutatókra faktoranalízist végeztünk (7. táblázat), melynek célja, hogy megvizsgáljuk, az előző pontozásos módszerben az egyenlő súlyozás miatt nem veszítettünk-e el túl sok információt. A faktoranalízis a változók korrelációs kapcsolatait modellezi kevés számú faktor, tényező függvényében. A faktor valamely posztulált, de közvetlenül nem mérhető látens tulajdonság változója, melynek hatása azonban mérhető változókban jelentkezik.

Az 5. táblázat a faktoranalízis során készített területi rangsort tartalmazza.

\section{TÁBLÁZAT}

A sport versenyképességének faktoranalizissel készitett területi rangsora

(The Final Rankings According to the Principal Component Analysis)

\begin{tabular}{lcc}
\hline \multicolumn{3}{c}{ Faktor rangsor } \\
\hline \multicolumn{1}{c}{ Terület } & Átlagos érték & Rangsor \\
\hline Bács-Kiskun & $\mathbf{0 , 4 3 5 9}$ & 9 \\
Baranya & 0,4653 & 8 \\
Békés & $\mathbf{0 , 3 3 4 3}$ & 19 \\
Borsod-Abaúj-Zemplén & $\mathbf{0 , 4 0 5 0}$ & 12 \\
Budapest & 0,8344 & 1 \\
Csongrád & $\mathbf{0 , 3 8 8 4}$ & 15 \\
Fejér & $\mathbf{0 , 4 1 1 4}$ & 11 \\
Györ-Moson-Sopron & $\mathbf{0 , 5 6 7 6}$ & 3 \\
Hajdú-Bihar & $\mathbf{0 , 3 8 9 5}$ & 14 \\
Heves & $\mathbf{0 , 3 5 2 2}$ & 16 \\
Jász-Nagykun-Szolnok & $\mathbf{0 , 3 9 6 7}$ & 13 \\
Komárom-Esztergom & 0,4200 & 10 \\
Nógrád & 0,2789 & 20 \\
Pest & $\mathbf{0 , 5 0 5 0}$ & 7 \\
Somogy & $\mathbf{0 , 5 5 2 9}$ & 4 \\
Szabolcs-Szatmár-Bereg & $\mathbf{0 , 3 4 4 6}$ & 17 \\
Tolna & $\mathbf{0 , 3 3 6 9}$ & 18 \\
Vas & $\mathbf{0 , 5 1 9 8}$ & 6 \\
Veszprém & $\mathbf{0 , 5 7 6 3}$ & 2 \\
Zala & $\mathbf{0 , 5 5 2 2}$ & 5 \\
\hline
\end{tabular}

Forrás: Saját számítás.

Az így kapott eredményeket kapcsolat vizsgálattal összevetettük a pontozásos módszer eredményeivel. A korrelációs kapcsolat mérésének legelterjedtebb mutatószáma a lineáris korrelációs együttható (jele: r), melynek alkalmazása során feltételezzük a változók közötti lineáris kapcsolatot (Pintér-Ács 2006). 
Az elvégzett számítások alapján a rangszámokra végzett korrelációs együttható (r) mértéke: 0,930827 , amely igen erős kapcsolatot jelent. Ez alapján elmondhatjuk, hogy a két számítás szinte tökéletesen ugyanazt az eredményt, területi sorrendet hozta.

\section{Összegzés}

Eredeti célunkat, - hogy a sporteredményekre ható egyéb tényezők alapján meghatározzunk egy komplex területi versenyképességi sorrendet Magyarországra - elértük.

Számításaink igazolásaként a sport-versenyképességi sorrendet kétféle módszerrel is - pontozásos, faktoranalízis - elvégeztük. A két módszert összevetve szinte ugyanazt az eredményt kaptuk. Mivel a faktoranalízis eredménye szorosan korrelál az egyenlö súlyozású rendszerrel, ezért az általunk használt módszer megalapozottnak tünik. A vizsgálatunk során használt sportra ható adatok szerint a magyarországi megyék komplex sport-versenyképességi sorrendje a következő (6. táblázat):

\begin{tabular}{|c|c|c|}
\hline \multicolumn{3}{|c|}{ Faktor rangsor } \\
\hline Sorrend & Megye, föváros & $\begin{array}{l}\text { Faktor } \\
\text { pontok }\end{array}$ \\
\hline 1 & Budapest & 0,8344 \\
\hline 2 & Veszprém & 0,5763 \\
\hline 3 & Györ-Moson-Sopron & 0,5676 \\
\hline 4 & Somogy & 0,5529 \\
\hline 5 & Zala & 0,5522 \\
\hline 6 & Vas & 0,5198 \\
\hline 7 & Pest & 0,5050 \\
\hline 8 & Baranya & 0,4653 \\
\hline 9 & Bács-Kiskun & 0,4359 \\
\hline 10 & Komárom-Esztergom & 0,4200 \\
\hline 11 & Fejér & 0,4114 \\
\hline 12 & Borsod-Abaúj-Zemplén & 0,4050 \\
\hline 13 & Jász-Nagykun-Szolnok & 0,3967 \\
\hline 14 & Hajdú-Bihar & 0,3895 \\
\hline 15 & Csongrád & 0,3884 \\
\hline 16 & Heves & 0,3522 \\
\hline 17 & Szabolcs-Szatmár-Bereg & 0,3446 \\
\hline 18 & Tolna & 0,3369 \\
\hline 19 & Békés & 0,3343 \\
\hline 20 & Nógrád & 0,2789 \\
\hline
\end{tabular}

Forrás: Saját számítás. 
Összegzésként, a faktoranalízis során készitett területi sorrendről (6. táblázat) leolvasható, hogy Magyarországon a sport-versenyképességi sorrendben a nyugati megyék többségében jobb pozícióban vannak, mint az ország keleti részén található megyék. A keleti területek közül a legjobb helyen Bács-Kiskun megye áll, míg a nyugati megyék közül a legrosszabb pozícióban Tolna megyét találjuk.

\section{Irodalom}

Ács P. (2006) A sport területi koncentrációja. Sport és tudomány napja konferencia kötet. Pécsi Tudományegyetem, Pécs.

Berey K.-Nemes Nagy J.(2002) A területi egyenlőtlenségek új indikátorainak és értékelési módszereinek lehetőségei. VÁTI Kht. Területfejlesztési Igazgatóság, Budapest.

Chikán A.-Czakó E. (2002) Kis nemzetgazdaságok versenyképessége a globális gazdaságban - a magyar példa. - Chikán A.-Czakó E.-Zoltayné Paprika Z. (szerk.) Vállalati versenyképesség a globalizálódó magyar gazdaságban. Akadémiai Kiadó, Budapest. 27-39. o.

Horváth Gy. (1998) Európai regionális politika. Dialóg Campus, Budapest-Pécs.

Horváth Gy. (2001) A magyar régiók és települések versenyképessége az európai gazdasági térben. - Tér és Társadalom. 2. 203-231. o.

Lengyel I.-Rechnitzer J.(2000) A városok versenyképességéről. - Horváth Gy.-Rechnitzer J. (szerk.) Magyarország terilleti szerkezete és folyamatai az ezredfordulón. MTA RKK, Pécs. 130-152. 0.

Nemes Nagy J. (1999) Elágazó növekedési pályák az ezredvégi Magyarországon. - Nemes Nagy J. (szerk.) Helyek, terek, régiók. ELTE Regionális Földrajzi Tanszék, Budapest. 65-86. o.

Palkovits I. (2000) Szempontok a területi versenyképesség értelmezéséhez. - Tér és Társadalom. 2-3. 119-128. o.

Pintér J.-Ács P. (2006) Bevezetés a sportstatisztikába. Dialóg Campus, Budapest-Pécs. 